\title{
PHOTOGRAMMETRIC ANALYSIS OF PETRUS CAMPERS FACIAL ANGLE AMONG ADULT URHOBO SUBJECTS \\ Enaohwo Mamerhi Taniyohwo
}

Department of Human Anatomy and cell biology, Faculty of Basic Medical Sciences, College of Health Sciences, Delta State University, Abraka, Nigeria. Email: enaohwotani@gmail.com

\begin{abstract}
Petrus Camper gained international repute among renaissance anthropologists, evolutionists and proponents of divisive scientific racism for his theory of the "facial angle" which they used as a vital cephalometric variable to validate their claim to racial and intellectual superiority. Standardized left lateral facial cephalograms of 1000 Urhobo subjects, between the ages of $18-60$ years, were collected over a 3-year period and subjected to geometric angular analysis to determine the magnitude of their respective facial angles. The mean value of Campers facial angle among sampled Urhobo subjects, $100.27^{\circ} \pm 4.06$ (males: $100.43^{\circ} \pm 4.34$; females: $100.11^{\circ} \pm 3.78$ ), was higher than that reported for European subjects $\left(100^{\circ}\right)$ by a numeric value of $0.27^{\circ}$. Analysis of obtained mean values of facial angle in this investigation showed that this craniometric variable was gender specific and may be show significant ethnic differences. These large numbers of cephalometric measurements provide a scientific basis for evaluation of physical variations in morphological human traits, not differences in human intelligence and brain complexity as was once proposed.

Keywords: Petrus Campers, Facial Angle, Photogrammetric Analysis, Urhobo.
\end{abstract}

\section{INTRODUCTION}

A Dutch artist-anatomist Petrus Camper (1722 -1789), introduced and popularized angular craniometry. His cephalometric measurement, facial angle, was perceived and perpetuated in literature of comparative anthropometry as the traditional mainspring of angular craniometry in man and his subspecies (Bolt, 1971). So profound, overwhelming and overpowering was the influence of Campers facial angle system on subsequent development of racist anthropology that Gould (1987) reported the sobriquet often used to describe Campers as the "the grandfather of scientific racism". Petrus Camper himself reported facial angles ranging from 100$95^{\circ}$ for antique Greco-Roman statues, $80^{\circ}$ for Europeans to $70^{\circ}$ for Orientals. In Campers now famous series of profiled crania, Black people, with angles of $70^{\circ}$, were not too far removed cranially, from Orangutans, with a documented facial angle of $42-58^{\circ}$ (Meijer, 1997; Meijer, 1999; Meijer, 2015). Except for descriptive values reported by Anibor et al., (2013), published literature documenting facial angle norms for adult Urhobo subjects, resident in Delta State of Nigeria was found to be evidently deficient. This paucity of documented angular cephalometric data for facial angle in the Urhobo sub-nationality, stimulated the interest in, and provided the drive for, the conduct of the current research investigation, thus serving as its justification of study. The Urhobos constitute the largest ethnic group in Delta State, with its 2006 population census figure of 4,098,391 Nigerian Citizens. We demonstrate and document the mean value of facial angle among Urhobo subjects.

\section{METHODOLOGY}

The left lateral cephalogrammetric profiles of a sample population of one thousand adult Urhobo subjects were evaluated. All selected study subjects were pure breed second generation Urhobo indigenes resident in Urhoboland for a period spanning 5- 10 years; their age range 
was 18 - 65 years. Urhobo subjects of ambiguous ethnic origin were therefore excluded from the sample frame. Basic demographic biodata of subjects including gender, age, place of birth and Local Government Area of residence (with duration of residency) were obtained among others. Precise but detailed subject enlightenment about the aim, objectives and standard nature of the present investigation was carried out following which informed consent was obtained.

To collect cephalometric data for facial angle, subjects were conveniently placed in the standard anatomical position with the head in the Frankfurt plane as decreed and documented by the 1884 World Congress on Anthropology in Germany. After a second inspection of subjects for possible covert signs of facial deformities, angular cephalometric landmarks were selected including, from above downwards, the left poron, the glabella, the nasion/nasal point and the pogonion. Campers facial angle in individual subjects was then measured as the space in degrees, formed by the intersection of the poron - nasion $(\mathrm{Pn}-\mathrm{N})$ line and the glabella pogonion $(\mathrm{Pg}-\mathrm{N})$ line.

Data were collated and subjected to analysis for descriptive (including mean, standard deviation, range) and inferential statistics. The William S Gosset t-test statistical tool in the IBM Statistical Package for the Social Sciences, v 23, was used to establish significant gender differences at a $p$ - value set at $\leq 0.05$.

\section{RESULTS}

Obtained mean value of facial angle, standard deviation and related descriptive statistical data are presented in tables 1 , for sampled male and female Urhobo subjects. Table 2 is a comparative presentation of facial angle from other population groups.

Table I: Minimum, maximum, mean values and standard deviation of facial angle among sampled male Urhobo subjects $(\mathrm{N}=1000)$.

\begin{tabular}{|l|l|l|l|l|l|}
\hline Variable & Range & Min & Max & Mean (SD) & $P$ \\
\hline Male campers facial angle & 22 & $88^{\circ}$ & $110^{\circ}$ & $100.43 \pm 4.34$ & 0.204 \\
\hline $\begin{array}{l}\text { Female campers facial } \\
\text { angle }\end{array}$ & 20 & $91^{\circ}$ & $111^{\circ}$ & $100.11 \pm 3.78$ &
\end{tabular}

Table 2: Comparative data on facial angle measurement in other population gruops.

\begin{tabular}{|l|l|l|}
\hline Author (Date) & Population/ethnic group & Facial Angle $\left({ }^{(}\right)$ \\
\hline Al Guniad (2007) & Yemeni & $91.0 \pm 3.0$ \\
\hline Anibor and Okobiah (2013) & Itsekiris & $83.4 \pm 4.1$ \\
\hline Emad and Naif (2012) & Palestinians & $92.2 \pm 4.1$ \\
\hline Peck and Peck (1970) & Europeans & $102.5 \pm 2.7$ \\
\hline Sahr and Naif (2012) & Saudi Arabians & $89.7 \pm 3.5$ \\
\hline Shweta (1970) & Malwa & $161.9 \pm 5,4$ \\
\hline Taniyohwo (2018) & Nigeria & $100.2 \pm 4$ \\
\hline
\end{tabular}

\section{DISCUSSION}

The current research investigated the degree of anthropometric variation that exist in obtained values of facial angle among a representative population of 1000 healthy adult Urhobo subjects, with the added objective of comparing study findings for significant intra-ethnic gender differences.
Evaluation of the 2013 angular facial norms reported by Anibor et. al., for a sample population of 100 Urhobo, and another report by Anibor and Okobiah (2013), for 100 Itsekiri subjects, did not demonstrate multiple significant gender differences (calculated $p$ value of 0.2637 as against selected $p$ value of $\leq 0.05$ ). While male and female Urhobo subjects in the Anibor 2013 series presented mean facial angles 
of $82.6^{\circ} \pm 6.3$ and $82.5^{\circ} \pm 4.9$ respectively, corresponding gender groups in the Itsekiri population sample mentioned herein presented angles of $83.8^{\circ} \pm 4.7$ and $82.9^{\circ} \pm 3.5$ respectively.

Comparative analysis of the larger Urhobo facial angle $\left(100.27^{\circ} \pm 4.07\right)$ and Campers documented value for Europeans $\left(80^{\circ}\right)$ reveals an arithmetic difference of 20.270 but a proximity with the reference mean European value of $102.5^{\circ} \pm 2.7$ reported by Peck and Peck (1970) for a sample population of fifty-two European adults. A progressive lowering is manifested in mean value of facial angle from the Palestinians $\left(92.17^{\circ} \pm 4.06\right)$ (Emad et al., 2011) through the Yemenis $\left(91.0^{\circ} \pm 3.0\right)$ (Al-Guniad et. al., 2007) to Saudi subjects $\left(89.66^{\circ} \pm 3.54\right)$ (Sahar and Naif, 2012). Shweta et al., (2014) reported mean value for Malwa (Central India) female population - $161.98^{\circ} \pm 5.42$ - is however observed to be at significant variance with the obtained mean value for female Urhobo subjects in the current research evaluation $\left(100.11^{0} \pm 3.78^{0}\right)$.
The aetiological basis for the observed physical variation in mean values of facial angle along ethnic, racial and gender lines seen in the present study is multi-factorial, being attributable to such considerations and influences as differences in geographical/ecological settings, socio-cultural backgrounds and even statistical preferences, including variations in selected sample size as well as proportion of male to female subjects in the selected sample population. This research finding of variation in physical anthropometric quantities is constant and stands out as the cardinal hallmark of all research investigations into known (and even unknown) angular cephalometric variables. On the principles and practice of physical anthropometric variation therefore, all anthropometrists must therefore stand.

In conclusion, these large numbers of cephalometric measurements provide a scientific basis for evaluation of physical variations in morphological human traits, not differences in human intelligence and brain complexity as was once proposed.

\section{REFERENCES}

1. Bolt C. 1971. Victorian attitudes to race. Routledge and Keagan Paul, London, 212.

2. Gould SJ. 1987. Petrus Camper's Angle, Natural History, 96 (7):14.

3. Anibor E, Okobiah R, Okpara I. 2013. Photometric analysis of the facial angle of the Urhobos in Nigeria. J of Med and Appl Bio-sci. 5 (1): 84 -93.

4. Anibor E, Okobiah R. 2013. A computer-assisted photometric analysis of the facial angle of the Itsekiris in Nigeria. Afri J of Cell Path 1:1:40-46.

5. Meijer MC. 1999. Race and Aesthetics in the Anthropology of Petrus Camper (1722-1789).

6. Meijer MC. 2015. "Bones, law and order in Amsterdam: Petrus Camper's morphological insights," Petrus Camper in Context: Science, the Arts, and Society in the Eighteenth-Century Dutch Republic, 185-211. Eds.

7. Peck H, Peck S. 1970. A concept of facial esthetics. Angle Orthod. 40(4):284-318.

8. Emad H, Susan AK, Nezar W, Alev A, Ahu A, Mahmoud AM. 2011. Evaluation of facial soft tissue parameters for Palestinians using Holdaway analysis. Saudi Dent J. 23(4): 191-195.

9. Al-Guniad T, Yamada K, Yamaki M, Saito I. 2007. Soft-tissue cephalometric norms in Yemeni men. Am J Orthod Dentofacial Orthop, 132 (5):e7 - 14.

10. Sahar A, Naif A. 2012. Holdaway soft-tissue cephalometric standards for Saudi Adults. King Saud Univ. J Dent Sc. 3: $27-32$.

11. Shweta R, Kamalshikha B, Varun H, Mohamed R, Himanshu K, Pulayampatt UB. 2014. Soft Tissue Cephalometric Norms for Central India (Malwa) Female Population. J Int Oral Health. 6(5): 5159. 